Artikel Penelitian

\title{
Hubungan Antara Lama Reaksi Suksinilasi dengan Sifat Fungsional Isolat Protein Bungkil Biji Jarak Pagar (Jatropha Curcas L.)
} Relationship between Time Reaction and Functional Properties of Physic Nut (Jatropha Curcas L.) Protein Isolate

Miftakhussolikhah $^{1^{*}}$, Chusnul Hidayat ${ }^{2}$, Pudji Hastuti $^{2}$

${ }^{1}$ Balai Penelitian dan Teknologi Bahan Alam Lembaga IImu Pengetahuan Indonesia (BPTBA LIPI) Jl. Jogja-Wonosari Km. 31,5 Gading, Playen, Gunungkidul, Yogyakarta

${ }^{2}$ Jurusan Teknologi Pangan dan Hasil Pertanian, Fakultas Teknologi Pertanian, Universitas Gadjah Mada, Yogyakarta

Korespondensi dengan penulis (miftalipi@gmail.com)

Artikel ini dikirim pada tanggal 18 April 2016 dan dinyatakan diterima tanggal 16 Juni 2016. Artikel ini juga dipublikasi secara online melalui www.jatp.ift.or.id. Hak cipta dilindungi undang-undang. Dilarang diperbanyak untuk tujuan komersial.

Diproduksi oleh Indonesian Food Technologists $®(02016$

\begin{abstract}
Abstrak
Isolat protein bungkil biji jarak pagar (Jatropha curcas L.) mempunyai sifat fungsional yang sesuai digunakan sebagai emulsifier, namun kelarutannya rendah pada $\mathrm{pH}$ netral. Modifikasi berupa suksinilasi perlu dilakukan untuk meningkatkan sifat fungsional isolat protein biji jarak sebagai emulsifier. Tujuan penelitian ini adalah untuk mengevaluasi pengeruh lama reaksi terhadap sifat fungsional isolat protein biji jarak tersuksinilasi. Pada penelitian ini, suksinilasi dilakukan menggunakan 0,1 g succinic anhydride/g protein selama 30, 60, 90, 120 dan 150 menit. Derajat suksinilasi (DS) ditentukan dengan menentukan gugus amino bebas menggunakan metode trinitrobenzene sulphonic acid (TNBS). Sifat fungsional yang dikaji meliputi sifat kelarutan, hidrophyl-lipophyl balance (HLB), kapasitas pembentukan emulsi dan stabilitas emulsi. Hasil evaluasi menunjukkan isolat protein biji jarak yang tersuksinilasi mempunyai sifat fungsional yang lebih baik dibanding isolat protein biji jarak native. Emulsi yang terbentuk dari isolat protein biji jarak tersuksinilasi adalah emulsi minyak dalam air. Lama reaksi suksinilasi yang menghasilkan sifat fungsional paling tinggi adalah 90 menit.
\end{abstract}

Kata kunci: Jatropha curcas L., bungkil, isolat protein, suksinilasi, emulsifier

\begin{abstract}
Protein isolates from defatted physic nut (Jatropha curcas L.) seed cake had suitable functional properties as emulsifier, but in neutral condition it had lack of solubility. Succinylation is needed to improve functional properties of protein isolate as emulsifier. The aim of this research was to evaluate effect of reaction time on the functional properties of succinylated physic nut protein isolate. In this experiment, succinylation was done using $0,1 \mathrm{~g}$ succinic anhydride/g protein for 30,60, 90, 120 and 150 minutes. Degree of succinylation (DS) was determined by analyzing free amino group of protein using trinitrobenzene sulphonic acid (TNBS) method. The functional properties of protein isolates such as, solubility profile, emulsifying capacities, emulsifying stability and hidrophyllipophyl balance (HLB) were evaluated. The result showed that functional properties of succinylated physic nut protein isolate were higher than functional properties of native protein isolate. Succinylated of physic nut protein isolate could form oil in water emulsion type. Succinylated of physic nut protein isolate for 90 minutes could produce protein isolate which had the highest functional properties among the modified protein.
\end{abstract}

Keywords: Jatropha curcas L., seed cake, protein isolate, succinylation, emulsifier

\section{Pendahuluan}

Jarak pagar (Jatropha curcas L.) merupakan suatu tanaman yang dapat dimanfaatkan sebagai sumber minyak dan mempunyai potensi produksi skala besar. Tanaman ini dapat tumbuh pada tanah kurang subur dan bijinya mengandung sekitar 30-40\% kandungan minyak (Veny $\mathrm{H}$ et al, 2009). Bagian tumbuhan ini, terutama bijinya mengandung phorbol esters yang membuatnya tidak enak dimakan dan beracun (Makkar et al, 1997) Hal ini yang menyebabkan jarak pagar digunakan sebagai nonedible vegetable oil yang dapat digunakan untuk pembuatan lilin, sabun dan produk lain. Penggunaannya yang paling luas adalah untuk pembuatan bahan bakar minyak (biofuel) untuk menanggulangi permasalahan bahan bakar fosil yang semakin menipis ketersediaannya.
Pemanfaatan minyak dari biji jarak pagar, menimbulkan limbah berupa bungkil biji jarak pagar. Selama ini pemanfaatan bungkil biji jarak pagar hanya sebagai pupuk organik dan pakan ternak (Jongschaap et al, 2007) Padahal kandungan protein pada biji jarak cukup tinggi. Menurut Abidah (2008) biji jarak pagar mempunyai kandungan protein $17,14 \%$. Setelah proses ekstraksi minyak, kandungan protein di dalam bungkil mencapai 56,40-63,80\% (Makkar et al, 1997) sedangkan menurut Prastowo (2009) kandungan protein yang ada pada bungkil biji jarak setelah ekstraksi solven adalah $57,73 \%$. Hal ini memicu dilakukannya pemanfaatan protein dari bungkil biji jarak untuk digunakan lebih lanjut sebagai sumber protein yang mempunyai peran fungsional yang lebih baik sehingga mempunyai nilai ekonomi yang lebih tinggi. 
Isolasi protein dapat ditempuh sebagai alternatif pemanfaatan protein dari biji jarak.

Produksi isolat protein saat ini berkembang menuju ke arah industri. Hal ini dikarenakan adanya perkembangan penggunaan dari produk ini di dalam pangan maupun non pangan (Sanchez-Vioque et al, 1999). Salah satu kegunaan dari isolat protein di dalam pangan adalah sebagai bahan campuran untuk meningkatkan nilai gizi suatu produk. Pemanfaatan isolat protein sangat tergantung pada sifat-sifat yang dimiliki oleh protein tersebut. Sebagai contoh, isolat protein dengan kapasitas pengikatan air dan minyak yang tinggi cocok digunakan dalam produk olahan daging dan roti, sedangkan isolat protein dengan kapasitas emulsi yang tinggi cocok digunakan untuk salad dressing, produk gula-gula (confectionaries), dan sup (Kanu, P.J. et al, 2007)

Isolat protein native banyak yang mempunyai sifat fungsional terbatas. Hal ini juga terjadi pada isolat protein biji jarak pagar sebagaimana telah dipelajari oleh Prastowo (2009) Isolat protein biji jarak mempunyai sifat fungsional yang baik pada suasana basa. Pada pH 9 kelarutan isolat protein mencapai $44,19 \%$, kapasitas emulsi $56,84 \%$ dan stabilitas emulsi $99,43 \%$. Bahkan pada $\mathrm{pH} 11$ kelarutan isolat protein biji jarak mencapai $91,32 \%$. Sementara pada $\mathrm{pH} 7$, yang merupakan kondisi yang paling sering digunakan untuk proses produksi produk pangan, justru menunjukkan hasil yang kurang baik (kelarutan $26,28 \%$, kapasitas emulsi $56,18 \%$ dan stabilitas emulsi $80,96 \%$ ). Padahal menurut Prastowo (2009) isolat protein yang dihasilkan dari bungkil biji jarak mempunyai sifat fungsional yang sesuai digunakan untuk emulsifier. Isolat protein biji jarak diharapkan mempunyai sifat fungsional yang lebih baik, sehingga dapat digunakan lebih luas dalam industri pangan khususnya sebagai emulsifier. Modifikasi secara kimia seperti suksinilasi sering dilakukan untuk meningkatkan sifat fungsional dari protein(Lawal, 2005)

Modifikasi isolat protein menggunakan succinyc anhidryde diharapkan dapat memperbaiki sifat fungsional dari protein. Setelah dilakukan modifikasi, perlu dilakukan karakterisasi sifat fungsional isolat protein tersuksinilasi, antara lain sifat kelarutan, hidrophyl-lipophyl balance (HLB), kapasitas pembentukan emulsi dan stabilitas emulsi. Hal ini dipandang penting dalam kaitannya dengan pemanfaatan di dalam produk pangan secara tepat.

Hingga saat ini, penelitian mengenai pengaruh lama suksinilasi isolat protein bungkil biji jarak pagar terhadap sifat-sifat fungsional (sifat kelarutan, hidrophyl-lipophyl balance/HLB, kapasitas pembentukan emulsi dan stabilitas emulsi) dari isolat protein yang dihasilkan belum tersedia. Oleh karena itu, perlu dilakukan penelitian mengenai permasalahan tersebut.

Tujuan penelitian ini adalah untuk mengevaluasi pengaruh lama reaksi suksinilasi isolat protein bungkil biji jarak pagar terhadap sifat-sifat fungsional isolat protein bungkil biji jarak pagar. Sifat-sifat fungsional yang dikaji terdiri dari sifat kelarutan, hidrophyl-lipophyl balance (HLB), kapasitas pembentukan emulsi dan stabilitas emulsi.

\section{Materi dan Metode}

Penelitian dilakukan di Laboratorium Rekayasa Proses dan Pengolahan, Laboratorium Kimia dan Biokimia Pangan, dan Laboratorium Bioteknologi Fakultas Teknologi Pertanian Universitas Gadjah Mada, Yogyakarta. Bahan baku yang digunakan adalah isolat protein yang berasal dari bungkil biji jarak pagar (Jatropha curcas L.) berukuran $<40$ mesh yang merupakan hasil samping dari proses ekstraksi minyak dari biji jarak pagar. Isolasi protein bungkil biji jarak pagar dilakukan dengan metode Jianmei et al (2007) yang telah disempurnakan oleh Prastowo (2009). Prinsip isolasi didasarkan pada pelarutan protein pada $\mathrm{pH}$ dengan kelarutan tertinggi yaitu $\mathrm{pH} 11$ menggunakan $\mathrm{NaOH} 1 \mathrm{~N}$ dan presipitasi protein pada $\mathrm{pH} 4$ (titik isoelektris) menggunakan $\mathrm{HCl} 1 \mathrm{~N}$. Isolat yang diperoleh selanjutnya dikeringkan menggunakan freeze dryer.

Isolat protein bungki biji jarak pagar dimodifikasi menggunakan succinic anhydride (suksinilasi). Suksinilasi dilakukan berdasarkan metode Groninger (1973) yang dimodifikasi dimana konsentrasi succinic anhydride yang ditambahkan adalah $0,1 \mathrm{~g}$ succinic anhydride/g isolat protein bungkil biji jarak pagar kering. Lama waktu reaksi divariasikan yaitu 30, 60, 90, 120, dan 150 menit.

\section{Derajat Suksinasi}

Penentuan derajat suksinilasi isolat protein dilakukan berdasarkan metode trinitrobenzene sulphonic acid (TNBS) oleh Jens Adler Nissen (1979) yang ditera absorbansinya pada $340 \mathrm{~nm}$.. Semakin banyak gugus amino yang bereaksi dengan succinic anhydride maka semakin sedikit gugus amino yang mampu bereaksi dengan reagen TNBS (Lawal, 2005). Derajat suksinilasi dihitung dengan membandingkan banyaknya penurunan gugus amino bebas isolat protein setelah suksinilasi terhadap banyaknya gugus amino bebas isolat protein native.

Isolat protein bungkil biji jarak pagar native dan tersuksinilasi selanjutnya dianalisis sifat fungsionalnya sebagai emulsifier. Sifat fungsional yang dianalisis terdiri atas sifat kelarutan, kapasitas dan stabilitas emulsi, serta nilai hydrophile-lipophile balance (HLB).

\section{Kelarutan Protein}

Kelarutan protein diketahui dengan cara menganalisis protein terlarut pada filtrat suspensi isolat protein pH 2-11 menggunakan metode Lowry (1951) dengan peneraan pada panjang gelombang $600 \mathrm{~nm}$. Kapasitas pembentukan emulsi dan stabilitas emulsi dilakukan dengan metode Lqari et al (2002) yang telah dimodifikasi, dimana analisis dilakukan dengan melarutkan $2,5 \mathrm{~g}$ isolat protein kering sampai volume 50 $\mathrm{ml}$. Analisis dilakukan pada filtrat suspensi protein pada $\mathrm{pH}$ 3, 7 dan 9 yang merepresentasikan kondisi asam, netral dan basa. 


\section{Nilai hydrophile-lipophile balance (HLB)}

Penentuan nilai HLB dilakukan dengan metode Janus et al (2006) yang telah dimodifikasi dimana pengukuran emulsi pada sampel dilakukan dengan menambahkan $5 \mathrm{ml}$ minyak goreng ke dalam $5 \mathrm{ml}$ larutan protein yang mempunyai konsentrasi $5 \mathrm{mg}$ protein $/ \mathrm{ml}$ larutan. Standar yang digunakan adalah formula yang dibuat dari Tween 80 dan Span 80 . Nilai HLB isolat protein dihitung dengan cara plotting terhadap standar yang telah dibuat dengan pendekatan volume non emulsi.

Data yang diperoleh diolah menggunakan Analysis of Variance (ANOVA) yang dilakukan dengan uji banding menggunakan Duncan Multiple Range Test (DMRT) pada tingkat kepercayaan 5\% (Montgomery, 2005)

\section{Hasil dan Pembahasan}

\section{Pengaruh Lama Reaksi}

Gambar 1 adalah derajat suksinilasi isolat protein jarak pagar (Jatropha curcas L.) pada lama reaksi suksinilasi $30,60,90,120$ dan 150 menit menggunakan $0,1 \mathrm{~g}$ succinic anhydride/g protein. Berdasarkan Gambar 1, dapat dilihat bahwa derajat suksinilasi isolat protein biji jarak pagar meningkat signifikan dengan semakin lamanya waktu reaksi suksinilasi $(P<0,05)$. Hasil tersebut sesuai dengan hasil suksinilasi pada pati jagung dan amaranth (Bandhari dan Singhal, 2002) dimana semakin lama waktu reaksi suksinilasi derajat suksinilasinya juga semakin meningkat. Hal ini disebabkan peningkatan laju dan waktu kontak succinic anhydride dengan pati yang akan membentuk succinyl-pyridinum intermediet.

Waktu kontak yang semakin lama menyebabkan semakin banyak succinic anhydride yang dapat bereaksi dengan protein, atau lebih spesifik terhadap gugus $\varepsilon$-amino lisin yang merupakan gugus yang paling banyak tersuksinilasi (Lawal, 2005). Secara umum, reaksi kimia akan berlangsung terus menerus hingga tercapainya titik ekuilibrium (Anonim, 2010). Sehinga, reaksi suksinilasi akan terjadi terus-menerus hingga mencapai ekuilibrium yang teridentifikasi jika kurva sudah mendatar.

Berdasarkan Gambar 1 terlihat bahwa pada menit ke-150 waktu suksinilasi, reaksi suksinilasi belum mencapai ekuilibrium karena masih mengalami peningkatan derajat suksinilasi. Namun dari menit ke90 ke menit 120 dan menit 120 ke menit 150 presentase kenaikan derajat suksinilasinya kecil $(5,10 \%$ dan $4,86 \%$ ) dibandingkan kenaikan dari menit 30 ke menit 60 dan dari menit 60 ke menit $90(22,68 \%$ dan $10,55 \%$ ). Mengecilnya derajat suksinilasi ini dapat terjadi karena pada menit ke-150, reaksi suksinilasi sudah mendekati titik ekuilibrium. Kemungkinan jika waktu suksinilasi dibuat lebih lama, kurva derajat suksinilasi tidak akan membentuk garis linier lagi melainkan garis mendatar. Hal tersebut juga terjadi pada derajat suksinilasi pati amaranth dan pati jagung dimana setelah suksinilasi selama lima jam, tidak terjadi peningkatan yang signifikan derajat suksinilasi pati-pati tersebut (Bandhari dan Sighal, 2002)
Kelarutan Isolat Protein

Kelarutan isolat protein native dan isolat protein tersuksinilasi tergantung pada $\mathrm{pH}$. Pada Gambar 2 ditampilkan kelarutan isolat protein native dan tersuksinilasi 30, 60, 90, 120 dan 150 menit pada berbagai $\mathrm{pH}$. Berdasarkan Gambar 2, dapat dilihat secara keseluruhan bahwa kelarutan isolat protein meningkat dengan meningkatnya lama waktu suksinilasi. Pada $\mathrm{pH} 11$ isolat protein native dan tersuksinilasi mempunyai kelarutan paling tinggi. Titik isoelektris isolat protein native dan isolat protein tersuksinilasi selama 30 menit berada pada $\mathrm{pH}$ 5. Isolat protein tersuksinilasi selama 60, 90, 120 dan 150 menit mempunyai titik isoelektris pada kisaran $\mathrm{pH} \mathrm{4}$. Titik isoelektris isolat protein native lebih tinggi dibanding titik isoelektris isolat protein tersuksinilasi. Nilai kelarutan pada titik isoelektris untuk isolat protein dengan derajat suksinilasi lebih kecil, lebih tinggi dibanding isolat protein dengan derajat suksinilasi lebih tinggi. Hal ini juga terjadi pada locust bean (Lawal et al, 2007), gluten gandum (Barber et al, 1982); protein lablab (Lawal, 2005); mucuna bean (Adebowale, 2008) dan soy protein (Franzen et al, 1976). Penurunan titik isoelektris terjadi karena penurunan muatan positif yang terdapat pada gugus $\mathrm{NH}_{2}$ akibat suksinilasi. Pada $\mathrm{pH} 4$ isolat protein sudah tidak memiliki muatan sehingga kelarutannya rendah, sedangkan isolat protein native kelarutannya lebih tinggi karena masih bermuatan positif. Isolat protein dengan derajat suksinilasi lebih rendah juga mempunyai muatan lebih positif dibanding isolat protein dengan derajat suksinilasi lebih tinggi pada $\mathrm{pH}$ 4. Oleh karena itu, nilai kelarutan isolat protein dengan derajat suksinilasi lebih rendah menjadi lebih tinggi dibanding isolat protein dengan derajat suksinilasi lebih tinggi (Lawal et al, 2007)

Selanjutnya pada $\mathrm{pH}$ yang lebih tinggi dari $\mathrm{pH}$ isoelektris, kelarutan protein meningkat dengan meningkatnya $\mathrm{pH}$ dan lama reaksi suksinilasi. Hal ini juga terjadi pada Brazil nut kernel globulin (Ramos et al, 2005) dan lentil globulin (Bora, 2002). Peningkatan muatan negatif lisin sebagai akibat dari perubahan muatan positif gugus amin lisin dengan muatan negatif gugus karboksil dari succinic anhydride, menghasilkan peningkatan interaksi terhadap air pada $\mathrm{pH}$ netral dan alkali (Franzen et al, 1976). Perubahan tersebut menyebabkan membukanya rantai polipeptida protein yang disebabkan tolak-menolak antara gugus karboksil asam amino yang telah mengalami suksinilasi dengan gugus karboksil asam amino lain. Berkurangnya interaksi antara protein-protein dan peningkatan interaksi protein-air menghasilkan peningkatan kelarutan (Lawal et al, 2007). Besarnya muatan negatif sebanding dengan derajat suksinilasi, sehingga peningkatan kelarutan akan meningkat dengan peningkatan lama reaksi dan derajat suksinilasi pada $\mathrm{pH}$ diatas isoelektris hingga $\mathrm{pH} 11$.

Kelarutan isolat protein menurun dari $\mathrm{pH} 2$ hingga titik isoelektris. Sementara kelarutan isolat protein menurun dengan meningkatnya lama reaksi suksinilasi pada kondisi asam hingga tercapainya titik isoeleektris. Penurunan kelarutan protein tersuksinilasi 
di bawah $\mathrm{pH}$ isoelektris dibandingkan dengan isolat protein native terjadi karena penurunan muatan positif yang terdapat pada gugus $\mathrm{NH}_{2}$ akibat suksinilasi dan kenyataan bahwa gugus karboksil berada pada bentuk tak terdisosiasi pada $\mathrm{pH}$ tersebut. Keadaan ini menyebabkan terjadinya agregasi sehingga kelarutannya rendah (Lawal et al., 2007).

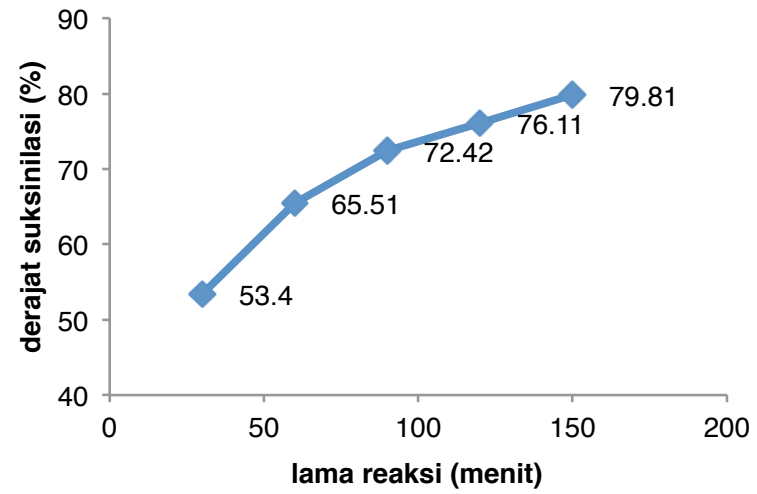

Gambar 1. Derajat suksinilasi isolat protein jarak pagar pada lama reaksi suksinilasi 30, 60, 90, 120 dan 150 menit menggunakan $0,1 \mathrm{~g}$ succinic anhydride/g protein dengan tiga kali ulangan

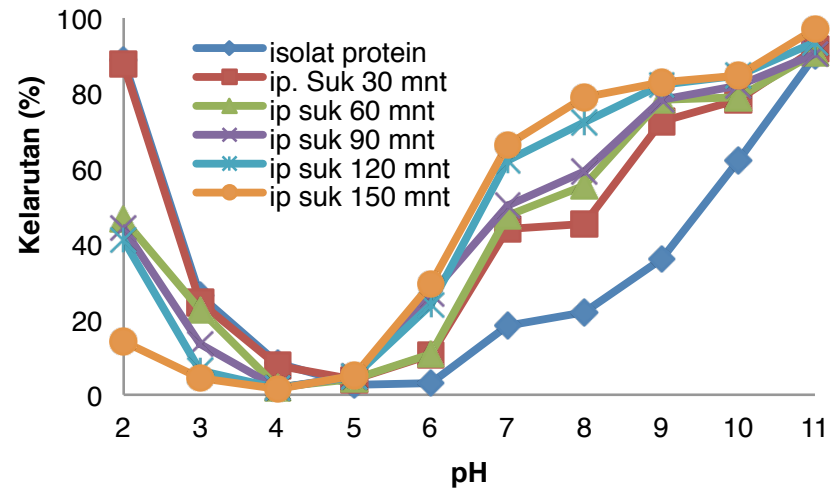

Gambar 2. Kelarutan (\%) isolat protein jarak pagar native dan tersuksinilasi 30, 60, 90, 120 dan 150 menit pada berbagai $\mathrm{pH}$

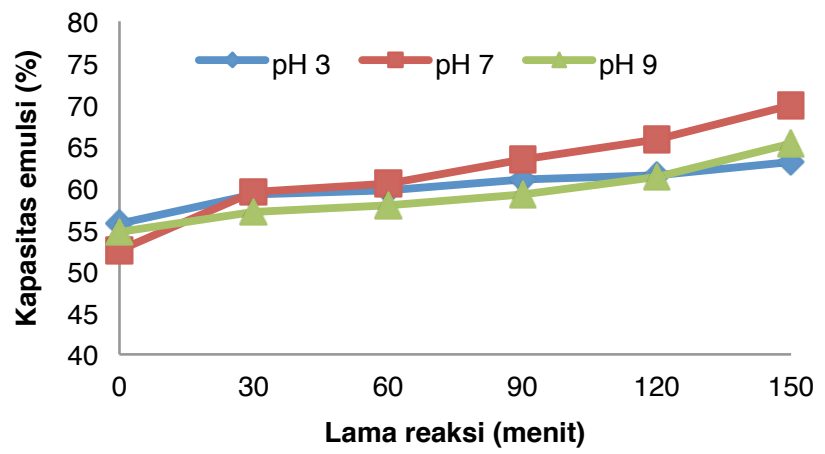

Gambar 3. Kapasitas pembentukan emulsi (\%) isolat protein jarak pagar native dan tersuksinilasi 30,60, 90, 120 dan 150 menit pada $\mathrm{pH} 3, \mathrm{pH} 7$ dan $\mathrm{pH} 9$

\section{Kapasitas Pembentukan Emulsi}

Kapasitas pembentukan emulsi merupakan fungsi dari $\mathrm{pH}$ dan juga derajat suksinilasi. Pada Gambar 3 ditampilkan kapasitas pembentukan emulsi isolat protein jarak pagar (Jatropha curcas L.) native dan tersuksinilasi 30,60, 90, 120 dan 150 menit pada $\mathrm{pH} 3, \mathrm{pH} 7$ dan $\mathrm{pH} 9$.

Berdasarkan Gambar 3, dapat dilihat bahwa kapasitas emulsi meningkat signifikan $(p<0,05)$ dengan meningkatnya lama suksinilasi yang berarti juga meningkatnya derajat suksinilasi.Peningkatan kapasitas emulsi setelah suksinilasi merupakan dampak dari peningkatan kelarutan pada $\mathrm{pH}$ 7. Suksinilasi juga menyebabkan tereksposnya gugus fungsional yang sebelumnya tersembunyi di bawah matrik protein dan hal ini akan meningkatkan interaksi interfase proteinminyak (Ma et al, 1987). Hasil yang sama juga telah dikemukakan untuk protein oat (Ma et al, 1987); tepung biji kapas (Childs et al, 1976) dan lablab bean (Lawal, 2005).

Kapasitas emulsi isolat protein native paling tinggi berada pada $\mathrm{pH} 3$ kemudian $\mathrm{pH} 9$ dan paling rendah $\mathrm{pH}$ 7. Pada isolat protein tersuksinilasi, kapasitas emulsi paling tinggi berada pada $\mathrm{pH} 7$ kemudian $\mathrm{pH} 3$ dan paling rendah pada $\mathrm{pH} 9$. Kapasitas emulsi tidak berbeda secara signifikan pada pH $3, \mathrm{pH} 7$ dan $\mathrm{pH} 9(\mathrm{p}>0,05)$. Kapasitas emulsi ini berkaitan dengan kelarutan protein pada berbagai $\mathrm{pH}$. Pada isolat protein tersuksinilasi, kenaikan aktifitas emulsi dari $\mathrm{pH} 3 \mathrm{ke} \mathrm{pH} 7$ berkaitan dengan kelarutan protein di $\mathrm{pH} 7$ yang lebih tinggi dari $\mathrm{pH} 3$. Kelarutan yang tinggi terjadi karena tolak-menolak antar asam amino akibat suksinilasi. Tolak-menolak tersebut menyebabkan gugus amin menjadi lebih terpapar karena terjadi pembukaan lipatan protein. Bertambahnya gugus karboksil akibat suksinilasi menyebabkan kenaikan muatan negatif pada isolat protein dan akan meningkatkan kelarutan isolat protein. Meningkatnya ekspos gugus amin yang merupakan sisi hidrofobik pada protein dan meningkatnya interaksi protein-air akan meningkatkan kapasitas emulsi (Lawal, 2005). Mekanisme protein dalam membentuk emulsi terjadi dimana sisi hidrofobik (gugus amin) berada di sisi dalam sementara sisi luar adalah sisi hidrofilik (gugus karboksil). Sementara pada $\mathrm{pH} 7 \mathrm{ke} \mathrm{pH} 9$ terjadi penurunan walau tidak secara signifikan. Penurunan ini dapat terjadi karena kelarutan yang terlalu tinggi mengakibatkan interaksi yang besar antara protein-air dan tak sebanding dengan interaksi protein-minyak yang lebih sedikit dan kurang terbentuk lapisan elastis interfase air-minyak. Sehingga emulsi yang terbentuk volumenya lebih kecil daripada di $\mathrm{pH} 7$.

\section{Stabilitas Emulsi}

Stabilitas emulsi berkaitan dengan $\mathrm{pH}$ karena berkaitan juga dengan kelarutan. Secara keseluruhan stabilitas emulsi isolat biji jarak pagar (Jatropha curcas L.) menurun dengan meningkatnya waktu suksinilasi. Berdasarkan Gambar 4, dengan semakin lamanya waktu suksinilasi ternyata menunjukkan tidak ada perbedaan yang signifikan $(p>0,05)$ stabilitas emulsi dari isolat protein native dan tersuksinilasi (30-90 menit). Selanjutnya stabilitas emulsi isolat protein biji jarak pagar menurun signifikan $(p<0,05)$ dari $90-150$ menit. Hasil itu juga terjadi pada isolat protein oat 
(Mirmoghtadaie et al, 2009). Walaupun terjadi peningkatan pada kelarutan dengan meningkatnya derajat suksinilasi, peningkatan muatan yang berlebih menurunkan interaksi protein-protein dan mencegah terbentuknya lapisan elastis pada interfase air dan minyak.

Interaksi protein-protein yang menurun menyebabkan berkurangnya jumlah peptida ukuran besar. Akibatnya, terbentuk lapisan interfase pada emulsi yang encer dan kurang stabil. Droplet-droplet emulsi juga menjadi kurang stabil (Chan et al, 2007). Hal ini tidak sesuai dengan penelitian pada lablab bean (El-Adawy, 2000), mung bean (Lawal, 2005), dan bambarra groundnut (Lawal et al, 2000) dimana dengan meningkatnya derajat suksinilasi, stabilitas emulsi isolat protein juga meningkat.

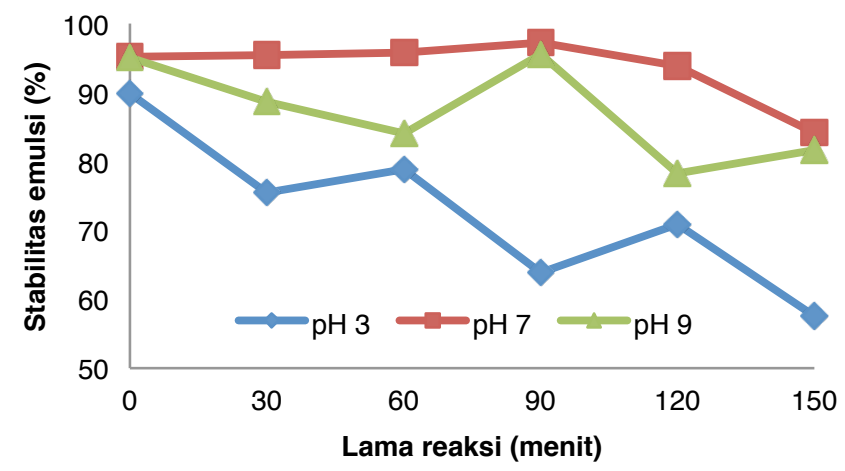

Gambar 4. Stabilitas emulsi (\%) isolat protein jarak pagar native dan tersuksinilasi 30,60, 90, 120 dan 150 menit pada $\mathrm{pH} 3, \mathrm{pH} 7$ dan $\mathrm{pH} 9$

Kandungan asam amino pada isolat protein memiliki peranan pada interaksi hidrofobik dan hidrofilik isolat protein. Menurut Apiwatanapiwat, et al (2009), biji Jarak pagar lebih banyak kandungan asam amino polar (28,57 mg/g protein) dibanding non polar $(24,22 \mathrm{mg} / \mathrm{g}$ protein). Fakta ini menyebabkan lebih banyak terjadi interaksi hidrofilik dibanding hidrofobik sehingga kurang terbentuk lapisan interfase yang kuat pada emulsi (Mirmoghtadaie et al, 2009).

Pada isolat protein tersuksinilasi dan native, stabilitas emulsi paling tinggi berada pada $\mathrm{pH} 7$ kemudian $\mathrm{pH} 9$ dan paling rendah pada $\mathrm{pH} 3$. Stabilitas emulsi berkaitan dengan kelarutan protein di berbagai $\mathrm{pH}$. Pada isolat protein tersuksinilasi, kenaikan aktifitas emulsi dari $\mathrm{pH} 3 \mathrm{ke} \mathrm{pH} 7$ berkaitan dengan kelarutan protein di $\mathrm{pH} 7$ yang lebih tinggi dari $\mathrm{pH} 3$. Sementara pada $\mathrm{pH} 7$ ke $\mathrm{pH} 9$ terjadi penurunan stabilitas yang dapat disebabkan kelarutan yang terlalu tinggi. Interaksi yang besar antara protein-air tak sebanding dengan interaksi protein-minyak yang lebih sedikit dan kurang terbentuk lapisan elastis interfase air-minyak sehingga emulsi yang terbentuk volumenya lebih kecil daripada di $\mathrm{pH} 7$.

\section{Nilai hydrophile/lipophile balance}

Tabel 1 memberikan informasi nilai hydrophile/lipophile balance (HLB) isolat protein biji jarak pagar (Jatropha curcas L.) native dan tersuksinilasi. Berdasarkan Tabel 1 dapat dilihat bahwa isolat protein biji jarak pagar native dan tersuksinilasi selama 30, 60, 90, 120 dan 150 menit mempunyai nilai HLB berbeda-beda. Isolat protein yang mempunyai nilai HLB antara 8-18 akan menghasilkan tipe emulsi minyak di dalam air $(\mathrm{O} / \mathrm{W})$. Semua isolat protein bungkil biji jarak pagar rendah lemak baik yang tersuksinilasi maupun native mempunyai tipe emulsi O/W. Oleh karena itu, isolat protein bungkil biji jarak pagar dapat digunakan sebagai pengemulsi dari produk-produk pangan yang mempunyai emulsi minyak di dalam air, seperti es krim, susu dan krimer untuk kopi (Anonim, 1980).

Menurut Apiwatanapiwat et al (2009), biji jarak pagar lebih banyak mengandung asam amino polar dibanding non polar yang menyebabkan lebih banyak terjadi interaksi hidrofilik daripada hidrofobik. Sehingga, tipe emulsi yang terbentuk jika menggunakan emulsifier isolat protein biji jarak pagar tersuksinilasi adalah emulsi minyak dalam air. Pada emulsi minyak dalam air, fase kontinyu adalah air sementara fase diskontinyu-nya adalah minyak.

Tabel 1. Nilai hydrophile/lipophile balance (HLB) isolat protein biji jarak pagar serta tersuksinilasi 30,60, 90, 120 dan 150 menit

\begin{tabular}{ccccc}
\hline \multirow{2}{*}{ No } & \multirow{2}{*}{ Isolat protein } & \multicolumn{3}{c}{ Nilai HLB (\%) pada $\mathrm{pH}$} \\
\cline { 3 - 5 } & & 3 & 7 & 9 \\
\hline 1 & native & $>15$ & $12,86-15$ & $>15$ \\
\hline 2 & suksinilasi 30 menit & $>15$ & $>15$ & $>15$ \\
\hline 3 & suksinilasi 60 menit & $>15$ & $>15$ & $>15$ \\
\hline 4 & suksinilasi 90 menit & $>15$ & $10,72-12,86$ & $>15$ \\
\hline 5 & suksinilasi 120 menit & $>15$ & $>15$ & $>15$ \\
\hline 6 & suksinilasi 150 menit & $>15$ & $>15$ & $>15$ \\
\hline
\end{tabular}

Isolat protein biji jarak pagar native dan tersuksinilasi mempunyai nilai HLB>8. Menurut McClements (1999) droplet emulsi yang dibentuk oleh surfaktan yang mempunyai nilai HLB yang ekstrim (>8) mudah mengalami coalescence. Hal ini disebabkan pada nilai HLB yang sangat rendah atau sangat tinggi, sebuah surfaktan mempunyai semacam surface activity yang rendah yang tidak dapat terkumpul secara cukup pada permukaan droplet. Oleh karena itu sistem emulsi ini tidak dapat bertahan terhadap coalescence.

Nilai HLB pada isolat protein native dan isolat protein tersuksinilasi $\mathrm{pH} 7$ ada di bawah 15. Stabilitas emulsi yang maksimal untuk emulsi minyak di dalam air terbentuk jika menggunakan surfaktan yang mempunyai nilai HLB antara 10-12 (McClements, 1999). Hal ini dikarenakan surfaktan tidak menurunkan tegangan antarmuka terlalu rendah, sehingga droplet emulsi tidak bisa secara mudah dirusak. Nilai HLB isolat protein native dan isolat protein tersuksinilasi $\mathrm{pH}$ 7 lebih rendah daripada isolat protein yang lain. Sehingga telah sesuai jika stabilitas emulsi yang terbentuk lebih tinggi dibanding yang lain, yaitu $97,18 \%$ pada isolat protein tersuksinilasi 90 menit di $\mathrm{pH} 7$ dan $95,23 \%$ pada isolat protein $\mathrm{pH} 7$. 


\section{Kesimpulan}

Perbandingan antara sifat fungsional isolat protein native dan isolat protein tersuksinilasi menunjukkan bahwa suksinilasi isolat protein biji jarak pagar dapat meningkatkan sifat fungsional isolat protein sehingga dapat dimanfaatkan sebagai emulsifier pada emulsi minyak dalam air. Reaksi suksinilasi yang menghasilkan sifat fungsional paling tinggi adalah selama 90 menit.

\section{Ucapan Terima Kasih}

Penulis menyampaikan penghargaan dan ucapan terima kasih kepada Prof (R). Dr. Gono Semiadi atas bimbingan serta arahan dalam penulisan artikel ini.

\section{Daftar Pustaka}

Abidah, N. 2008. Sintesis Metil Ester Dari Minyak Jarak Pagar (Jatropha curcas) Menggunakan Freeze Dried Lipase Kecambah Jarak Pagar. Tesis, Fakultas Teknologi Pertanian. Yogyakarta: Universitas Gadjah Mada.

Adebowale, Y.A. dan Adebowale, K.O. 2008. Emulsifying Property of Mucuna Flour and Protein Isolates. Journal of Food Technology. 6 (2): 66-79.

Anonim. 1980. The HLB system a Time Saving Guide to Emulsifier Selection. Delaware: ICI Americas Inc.

Anonim. 2010. Kinetic of the Chemical Reaction. http://sci.informika.ru/text/database/chemy/Enu/Dat a/ Ch1_5.html\#_CHEMICAL_EQUILIBRIUM. Diakses tanggal 3 Juni 2015.

Apiwatanapiwat, W., Vaithanomsat, P., Smokliang, P. dan Malapant, T. 2009. Optimization of Protein Hydrolysate Production Process from Jatropha curcas Cake. Proceedings of World Academy of Science, Engineering and Technology. 41: 20703740.

Bandhari, P.N. dan Singhal, R.S. 2002. Studies on the Optimisation of Preparation of Succinate Derivatives form Corn and Amaranth Straches. Carbohydrate Polymers. 47: 277-283

Barber K.J. dan Warthesen, J.J. 1982. Some Functional Properties of Acylated Wheat Gluten. J Agric Food Chem. 30: 930-934

Bora, P.S. 2002. Functional Properties of Native and Succinylated Lentil (Lens culinaris) Globulins. Food Chemistry. 77: 171-176.

Chan, W. M. dan Ma, C. Y. 1999. Acid Modification of Proteins from Soymilk Residue (Okara). Food Research International. 32: 119-127.

Childs, E.A., dan Park, K.K. 1976. Functional Properties of Acylated Glandless Cotton Seed Flour. Journal of Food Science. 41: 713-714.

El-Adawy, T.A. 2000. Functional Properties and Nutritional Quality of Acetylated and Succinylated Mung Bean Protein Isolate. Food Chemistry. 70: 83-91

Franzen, K.L. dan Kinsella, J.E. 1976. Functional Properties of Succinylated and Acetylated Soy Protein. Journal of Agricultural and Food Chemistry. 24: 788-795.
Groninger, H.S. 1973. Preparation and Properties of Succinylated Fish Myofibrillar Protein. Journal of Agricultural and Food Chemistry. 21: 978-981.

Janus, P.F., Fernandes, L.L., Formigo, F.R., Reis, M.F., Junior, T.N., Soares, L.A.L., dan Egito, S.T., 2006. Micro-emultocrit Technique: a Valuable Tool for Determination of Critical HLB Value of Emulsions. AAPS PharmSciTech. 7(1):E146-E152

Jens Adler-Nissen. 1979. Determination of the Degree of Hydrolysis of Food Protein Hydrolysates by Trinitrobenzenesulfonic Acid. J. Agric. Food Chem. 27 (6): 1256-1262

Jianmei, Y., Ahmedna, M. dan Goktepe, I. 2007. Peanut Protein Concentrate: Production and Functional Properties as Affected by Processing. Food Chemistry. 103: 121-129.

Jongschaap, R.E.E., Corre, W.J., Bindraban, P.S. dan Brandenburg, W.A. 2007. Claims and Facts on Jatropha curscas L. Wageningen: Plant Research International B.V.

Kanu, P.J., Kerui, Z., Ming, Z.H., Haifeng, Q., Kanu, J.B. dan Kexue, Z., 2007. Sesame Protein 11: Functional Properties of Sesame (Sesamum indicum L.) Protein Isolates as Influenced by $\mathrm{pH}$, Temperature, Time and Ratio Flour to Water During Its Production. Asian Journal of Biotecnology. 2 (5): 289-301.

Lawal, O.S., 2005. Functionality of Native and Succinylated Lablab Bean (Lablab purpureus) Protein Concentrate. Food Hydrocolloids. 19: 6372.

Lawal, O.S., Adebowale, K.O. dan Adebowale, Y.A. 2007. Functional Properties of Native and Chemically Modified Protein Concentrates from Bambarra Groundnut. Food Research International. 40: 1003-1011

Lawal, O.S. dan Dawodu, M.O. 2007. Maleic Anhydride Derivatives of a Protein Isolate: Preparation and Functional Evaluation. Eur Food Res Technol. 226: 187-198.

Lowry, O.H., Roserburgh, N.J., Farr, A.L., Randall, R.J. 1951. Protein Measurement With the Folin-Phenol Reagents. J. Biol. Chem. 193:265-275

Lqari, H., Vioque, J. Pedroche, J. dan Millan, F. 2002. Lupinus angustifolius Protein Isolates: Chemical Composition, Functional Properties and Protein Characterization. Journal of Food Chemistry. 76: 349-356.

Ma, C.Y. dan Wood, D.F. 1987. Functional Properties of Oat Proteins Modified by Acylation, Trypsin Hydrolysis or Linoleate Treatment. Journal of American Oil Chemist Society. 64: 1726-1731.

Makkar, H.P.S., Becker, K., Sporer, F. dan Wink, M. 1997. Studies on Nutritive Potential and Toxic Constituents of Different Provenances of Jatropha curcas. Journal Agriculture Food Chemistry. 45: 3152-3157.

McClements, D. J., 1999. Food Emulsions Principles, Practice, and Techniques. New York: CRC Press.

Mirmoghtadaie, L., Kadivar, M. dan Shahedi, M. 2009. Effects of Succinylation and Deamidation on 
Functional Properties of Oat Protein Isolate. Food Chemistry. 114: 127-131.

Montgomery, D.C. 2005. Design and analysis of experiments. Sixth Edition. Canada: John Wiley \& Sons, Inc.

Prastowo, Y.B. 2009. Isolasi dan Karakterisasi Sifat Fungsional Protein dari Bungkil Biji Jarak Pagar (Jatropha curcas L.). Skripsi, Fakultas Teknologi Pertanian. Yogyakarta: Universitas Gadjah Mada.Gadjah Mada.

Ramos, C.M.P. dan Bora, P.S. 2005. Functionality of Succinylated Brazil Nut (Bertholletia excelsa HBK)
Kernel Globulin. Plant Foods for Human Nutrition. 60: 1-6.

Sanchez-Vioque, R. 1999. Protein Isolates from Chickpea (Cicer arietinum L.): Chemical Composition, Functional Properties and Protein Characterization. Food Chemistry. 64: 237-243.

Veny, H., Baroutian, S., Aroua, M.K., Hasan, M., Raman, A.A. dan Sulaiman, N.M.N., 2009. Density of Jatropha curcas Seed Oil and its Methyl Esters: Measurement and Estimations. Int $\mathrm{J}$ Thermophys. 30: 529-541. 